\title{
Reference, evaluation and codes of culture in Russian and Czech proverbs of truth and lie
}

\author{
Olga B. Abakumova - Jiri Korostenski
}

DOI: 10.18355/XL.2020.13.02.10

\begin{abstract}
The paper deals with problems of evaluation, reference and typology of proverbs. The study is based on Russian and Czech proverbs of truth and lie that are classified according to different types of reference and ways of expressing evaluation. The research shows universal and national specific features of semantics and pragmatics in Russian and Czech proverbs that are revealed by means of cognition-discourse model of proverbs' sense actualization. The comparative analysis showed that Czech proverbs tend to evaluate the referential situation, while Russian proverbs of truth mostly focus on man's behavior, though both Slavic language cultures explicitly or implicitly recommend ethic norms of social behavior.
\end{abstract}

Key words: proverbs, reference, evaluation, Russian, Czech, cultural codes

\section{Introduction}

Proverbs are the most complex signs of the language. Many scholars still doubt their language status and consider them to be texts, speech units. The third group of researchers define them as units of hybrid nature, combining language and textual characteristics. But the status does not influence their functioning as they have such specified generalized meaning that reveals itself fully only in the context. That is why talking of proverbs we should pay attention not only to its semantics but to its pragmatics as well, so it is topical to discuss reference in proverbs (Frolova, 2007). Evaluation in proverbs and ways of expression are also the problem under discussion in paremiology and linguistics. Some researchers claim that it is the whole situation of reality that is evaluated by means of the proverb. Another group of scholars argue that they may evaluate constituents of the situation: objects, people, or their behavior. N.D. Arutjunova classifies evaluative meaning into two main groups: general evaluation marked by adjectives "good, bad" and their synonyms, and particular evaluative meanings like gedonistic (pleasant, tasty), psychological (interesting, content), esthetic (beautiful), ethical (moral, immoral), utilitarian (useful), normative (right, wrong), teleological (effective, successful) (Arutjunova, 1999). E.M. Volf offers evaluative frame for describing the process of evaluation which includes: the object of evaluation, the subject of evaluation, evaluative predicate, and evaluative scale based on stereotype (Volf, 2009).

\section{Methods and Materials}

Cognition-discourse model of proverb's sense actualization (CDM model) (Abakumova, 2012 ) is offered in this paper to reveal universal and specific features of proverbs' evaluation and bring out the possible ways of their expression combined with different types of reference. The language material for study is Russian and Czech paremic discourse about truth and lie based on dictionary data (Bittnerová, Schindler, 2003; Мокиенко, Никитина, Николаева, 2010), and texts are taken from national corpora, Russian and Czech (www.corpora.ru). Making use of several most famous and authoritative dictionary sources, the authors selected more than 500 Russian and about 100 Czech proverbs of this thematic group and a large number of contexts of their usage in newspaper articles and texts of fiction. The results are represented by the formalized language offered by A. Wierzbicka (Wierzbicka, 1980) and extended by O. Abakumova, adding frame analysis and the idea of qualitative. The CDM model has a four-part structure which presents: Kommunikativa communicative constituent, dealing with the choice of communicative strategy (Habermas, 1987), Konstativa - cognitive constituent, reflecting proverbial scenario as imposition of three 
types of frames (imagery, generalised and occasional), Representativa - expressive constituent, connected with expressing modality, evaluation and illocution and Regulativa regulative constituent, responsible for perlocutive effect of proverb usage, revealing cultural social norms and recommendations how to behave in the tradition of certain culture.

\section{Results and Discussion}

The proverb in this paper is defined as a phraseological unit with the structure of a sentence (Baranov, Dobrovolskij, 2008), practical evaluative judgment used in speech as a tactic means of communicative strategy realization (Abakumova, 2012). The proverb is the sign of the situation; it has a logical and syntactical structure. The use of proverb in the actualized form presupposes that the speaker and the listener are familiar with pragmatic conventions. In order to use the proverb correctly in a context, the speaker should do the following:

- Estimate the communicative situation and choose a communicative strategy;

- Estimate referential situation, state hierarchy of the actants and circumstances, their relationships, type of situation to find an analogy with the semantic invariant of the proverb;

- Choose the necessary proverb able to model the situation and evaluate it according to the speaker's attitude and needs;

- Give recommendations to the listener, making him accept the speaker's attitude, and choose a certain way of social behavior common for the culture in question.

It is necessary to single out explicated and implicated means of evaluation in proverbs.

Explicated means are the following: comparative terms of evaluation (Правда светлее солния - Truth is brighter than the sun), non-comparative terms of general value (Правда хорошо, а счастье лучше - Truth is good, and happiness is better), negative patterns (Neni šprochu, aby nebylo pravdy trochu - No gossip without little truth), melioration qualifiers (Кто за правду горой, тот истинный герой - The one who stands out for truth is a true hero), pejorative qualifiers (Déti, opilí a blázni mluví pravdu - Children, drunk and mad people speak the truth ), prediction (Lež má krátké nohy, daleko neujde - Lie has short legs, it will not go far), numeral means ( Lepši hrst pravdy, než pytel lži -Better handful of truth than the sack of lie).

Implicated evaluation is revealed trough codes of culture (see definition in Kovshova, 2013, Krasnykh, 2016), the focus of speaker's interest (see Van Valin, 1993), deontic norms of social behavior characteristic of a certain culture (Abakumova, 2012).

Our referential-evaluative classification of proverbs is based on typology offered by $\mathrm{O}$. E. Frolova (Frolova, 2007), who singles out three types of proverbs according to their referential characteristics:

- $\quad$ proverbs with occupied actants " positions with the predicate;

- $\quad$ proverbs with free, non-occupied actants'positions;

- $\quad$ proverbs with formally occupied but semantically vague, not clear actants'positions.

We extend this typology adding evaluative and comparative aspects (Abakumova, Korostenski 2013) and this time, bring out explicit and implicit ways of evaluation expression in Russian and Czech proverbs of truth.

- The first type of proverbs with occupied actants' positions covers $26 \%$ of Czech and $20 \%$ of Russian proverbs of truth and lie. According to the semantics of the noun group in the position of the subject, two subtypes, with referentially free and bound actants, are differentiated. 
- Referential free actants can be expressed by the following nouns, used metaphorically or metonymically to point out to the referent and evaluate it according to the cultural stereotypes.

- the animal name: Не прав медведь, что корову съел, не права корова, что в лес зашла (Wrong is the bear that ate the cow, wrong is the cow that went to the woods), Кулик не велик, а все-таки птииа (Sandpiper is small, but still it is a bird) that corresponds to zoomorphemic code of culture which is revealed only in Russian proverbs of truth and not found in Czech. This code implicates negative evaluation of the object in question but estimates the situation positively in general and stresses the idea of social justice included in the Russian cultural image of truth. (About social justice as one of the senses of the old Russian word "правда" see CAP-4 1793: 1043). The recommended norms are ethical One should be fair (see the classification of deontic norms in proverbs in Karasik 2002).

○ the plant name: И ракитовыц куст за правду стоит (Even the brittle willow stands out for the truth), И трава в поле виноватого выдает (And the grass in the field gives the guilty away). Phitonimic code is also Russian specific and as well points to the idea of social justice in proverbial Russian concept of truth. The actant and its actions are evaluated positively as they fight for justice. Once again, the ethical norms of social behavior are recommended (One should behave fairly).

- The material (object) as representative of artifactive code is found in both cultures, very often it is associated with gold or money: (Neni všechno zlato, co se leskne, neni všechno pravda, co pleskne = Не все золото, что блестит, не все правда, что болтают (Not all is gold that glitters); Penize mohou mnoho, a pravda kraluje Деньги могут многое, а правда все (Money can do a lot of things but truth is as powerful as a king). Besides the opposition "gold/money vs truth" that is universal in two languages in Czech proverbs, the opposition "handful vs sack" is revealed, which shows a combination with somatic and numeral codes of culture. Truth is evaluated both positively and negatively according to the object it is opposed to. It has a positive value if compared with hope and lie (Lepši hrst pravdy (jistoty), než pytel naděje - Better have handful of truth than the sack of hope; Lepši hrst pravdy, než pytel lži - Better handful of truth than the sack of lie).

But the value is negative if truth is compared with power (Lépe s hrst moci, než pravdy s pytel - Better handful of power, than the sack of truth). The recommended norms here are utilitarian.

- The gastronomical code of culture is found in both languages as well: Заработанный ломоть лучше краденого каравая (The earned slice of bread is better than stolen cottage loaf), Lepši trpká pravda, než sladká faleš = Лyчue горькая правда, чем сладкая ложь (Better bitter truth than sweet hypocrisy). In Russian, we have imagery connected with bread as typical Russian meals. In Czech, it is associated with taste, perhaps mostly drinks (famous Czech beer) that can be bitter or sweet. Ethical norms are recommended (One should be honest and behave honestly).

- $\quad$ Esthetic code is presented in Russian: Песня - правда, сказка(басня) - ложь (Song is truth, fairy-tale (fable) is a lie). Ethic norms through folklore means

XLinguae, Volume 13 Issue 2, April 2020, ISSN 1337-8384, ISSN 2453-711X 
recommend not to tell lies. Songs are estimated highly as they presuppose sincerity, fairy-tale is associated with lies and is evaluated negatively. Popular wisdom in Russia does not recommend to listen to tales/lies. Utilitarian norms advise not to be credulous.

- Costume code: Ha воре шапка горит (The cap burns covering the head of the thief). Ethical norms of behavior are recommended.

- Religious code of culture is universal: Бог правду видит, да не скоро скажет (God sees the truth but is not in a hurry to tell). In Russian proverb this time, utilitarian norms are recommended (One should take care of yourself). Boží mlýny melou pomalu, ale jistě (God sees everything, and works/helps slowly but fairly, safely). Ethical norms are recommended (One should be patient and hope for the better).

Proverbs of this group evaluate both the situation in general and the object as part/element of the situation. In their semantic and pragmatic structure, one can single out both wide and narrow focus of the speaker's interest. For the evaluation purpose, different codes are used. In Russian, they are more numerous than in Czech.

\section{I.2. Proverbs with referentially bound actants are numerous in both language cultures.}

a) personal noun: Pro pravdu se lidé rádi hněvaji (People are often angry with those who speak the truth), За правду Бог и добрые люди (God and kind people always stand out for the truth ); Král daleko, Bůh vysoko, pravdy a spravedlnosti v svètě málo. (The King is far away, God is high above, and truth with justice are rare on the earth). The anthropogenic code of culture prevails in both languages, though it sometimes is combined with religious code. Ethical norms are recommended, ethical behavior is highly estimated in both cultures.

b) evaluative noun: Prítel jest, kdo pravdu mluvi, ne kdo pochybuje (A friend is the one who tells the truth, and not the one who doubts); Моменники повздорили -u правда наружу (Scoundrels quarreled - and the truth came out). Anthropogenic code is used, people are evaluated according to their deeds. Ethical norms prevail.

c) somatic noun: Правдивая рука правдой живет (The right hand lives rightly, right person behaves honestly). Somatic code is often used.

d) proper name: Окул бабу надул, да и Окула баба надула (Okul cheated a woman, and the woman cheated him back). Anthropogenic code prevails to convey ethical norms of behavior.

Using the extended metalingual apparatus we offer to convey the sense of actualized proverb Král daleko, Bůh vysoko, pravdy a spravedlnosti v světě málo= Король далеко, Бог высоко, а правды и справедливости на земле мало (The King is far away, God is high above, and truth with justice are rare on the earth).

Kommunikativa: wishing to warn you against the trouble caused by dishonest people

Konstativa: I say: The King is far, the God is high above, take care of yourself

Representativa: I hope you understand that it is the right and useful thing to do

Regulativa: Make your mind not to hope for other people's help and try to solve the problem all by yourself (utilitarian norms of social behavior are recommended). 


\section{- Proverbs with free, non-occupied positions of actants (32\% of Czech and $45 \%$ of Russian proverbs)}

Proverbs with free actants' positions have often prescriptive character and mostly convey correspondence to norms than estimation. The position of actant is not occupied, so the participant of the communicative situation is "inserted" into the proverbial situation, taking the free place, mainly the place of the subject.

2.1. In Czech proverbs of this type infinitive model prevails (17 out of 32\%): Ohně nelze upáliti, vody utopiti, větru udusiti a pravdě zahynouti (It is not possible to burn fire, to drown water, to strangle wind and to wipe out truth). Лучше умереть, чем неправду терпеть (Better die than suffer from deception). Natural code and anthropogenic codes of culture are used here to convey ethical norms and positive evaluations of honest, decent behavior.

2.2. In Russian proverbs the most numerous are imperative sayings, stimulating the listener for certain (ethical) behavior: Правду молвишь, правду и чини = Pravdu kaž, spravedlivě važ (If you speak the truth, behave correspondingly, justly). These proverbs show that the Czech concept of truth also includes the idea of justice.

2.3. Besides, this type of proverbs covers generalized-personal sentences: Любишь кататься, люби и саночки возить =Bez práce nejsou koláče (If you like to go taboganing, you should like to carry sledges up the hill); Co zaseješ, to sklidiš - Чmo noceemb, mo u пожнешь (As you sow, you shall reap); S poctivostí nejdál dojdeš (With honour you will go the farthest) and indefinite-personal statements:Что ворам с рук сходит, за то воришек бьюm (Little thieves are punished for what is acceptable with big thieves); Neni všecko pravda, co se pěkně mluví. Agricultural and actional codes are used to convey ethical norms of behavior and express corresponding evaluation of man's behavior. Ethical norms prevail.

2.4. Passive constructions: Не пойман - не вор (When a person is not accused, he is not a criminal). Anthropogenic code helps to pass utilitarian norms of social behavior and neutral evaluation of the person and his behavior (One should not be too quick to judge).

2.5. Incomplete sentences: Bрет как сивый мерин. Lže, jako když tiskne. (Lies like an old horse). Zoomorphemic code is used to implicate negative evaluation and convey ethical norms of behaiviour (One should not tell lies).

Evaluation is focused on man's behavior and is conveyed through predicate focus of speaker's interest mostly by means of actional codes of culture.

Using our formal language one can describe Russian proverb “Правду молвишь, правду и чини" as far as its sense actualization is concerned in the following way:

Kommunikativa: wishing to warn you against immoral behavior,

Konstativa: I say, that one should act honestly if he speaks the truth

Representativa: I hope you understand that it is right

Regulativa: Make your mind and behave correspondingly, be good, and just (ethical norms of social behavior are recommended).

- Proverbs with positions of actants that are formally occupied but semantically vague cover $45 \%$ of Czech proverbs and $35 \%$ of Russian.

3.1. Evaluation of moral qualities of people (spiritual code of culture) is done by means of substantiated adjectives and numerals: Nejspiše blázen a děti pravdu mluví $=$ Глупьй да мальй правду говорят (The silly and the little tell the truth); Честный правды не боится (The honest are not afraid of the truth).

3.2. The core of the group is occupied by the proverbs with actants expressed by the nouns naming action or abstract notion: Правда светлее солнца (Truth is lighter than the sun); Правда не стареет (Truth never grows old); Правда истомилась и лжи покорилась (Truth got tired and resigned to the lie); Pravda ve vodě neutone a v ohni neshoř $i=\Pi$ Правда 8 
воде не тонет и в огне не горит (Truth does not sink in water and does not burn in fire). Natural code of culture is combined with anthropogenic to express positive evaluation of the situation and the idea of truth in both language cultures.

The proverbs of this type are referentially vague; they name the situation without singling out actants (participants). If actant is interpreted as an indirect one, the metaphorical noun group is considered to be trope (allegory, antonomasia) and corresponds to personal actant. If it is thought to be used in direct meaning, the noun group in the position of the subject is perceived as the name of quality.

3.3. Another group of proverbs inside this type is the proverbs with pronouns 'each' and 'every' in the place of actant: Всяк правду хвалит да не всяк ее бает (Each person praises the truth, but not each one tells it), Каждому по делам его (Every man must get what he deserves). Actional code helps to estimate negatively the situation where people break the norms of contract or equity.

The same type includes complex sentences with relative pronouns "one...who" in the actant place: Кто заварил кашу, тот ее и расхлебывает (The one who caused the trouble should solve the problem); Kdo lže, ten krade=Kmо лжет, mom и крадет (The one who lies is mostly a thief), Kdo nevěř́, at' tam běži (If one does not believe, let him go to see for himself); Кто за правду горой, тот истинньй герой (The one who stands out for truth is a true hero). Gastronomical code is combined with actional to express evaluation of the situation and man's behavior. Ethical norms are recommended.

One more subgroup is differentiated inside the type III that is characterized by the use of indefinite pronouns „someone“ ,somewhere“ etc.: Где-нибудь да сыщется правда (There is the truth somewhere to be found).

The actualized sense of Czech proverb Pravda ve vodě neutone a v ohni neshoři (Truth does not sink in water and does not burn in fire) can be described in the following way:

Kommunikativa: wishing to encourage you to hope for the better

Konstativa: I say, that truth will never be lost and is going to come out in the end

Representativa: I hope you believe that it is true

Regulativa: Make up your mind and keep waiting for the victory of truth (ethical norms of social behavior are recommended).

\section{Conclusion}

Reference in proverbs is combined with an evaluation that may be expressed by means of explicative and implicative means. The reference-evaluative classification conveys evaluation, both explicitly and implicatively. Three reference types correlate with different focuses of the speaker's interest. The first type of proverbs, with occupied places of actants, evaluate people, objects, and events having noun or sentence focus of interest. Evaluation is conveyed through different codes of culture. Amount of Russian and Czech paremias is comparatively equal. The second type with free actant positions prevails in Russian. Evaluation is done through actional codes mostly and is connected with the predicate focus of the speaker's interest. The third type is more often found in Czech proverbs. Proverbs of this type evaluate the whole situation through allegoric images of abstract essences that are personified and invested with human qualities. These proverbs have wide, sentence focus of the speaker's interest, and evaluation is conveyed through anthropogenic or actional codes mostly. Ethical norms prevail over utilitarian in both language cultures.

\section{Bibliographic references}

ABAKUMOVA, O. B. 2012. Poslovitsy v jazyke, soznanii i kommunikatsii. SaintPetersburg: Aleff-Press. ISBN 978-5-905966-04-0.

ARUTJUNOVA, N. D. 1999. Jazyk I mir cheloveka. Moscow: Jazyki russkoj kultury. ISBN 5-7859-0027-0. 
BARANOV, A. N. - DOBROVOLSKIJ, D. O. 2008. Aspekty teorii frazeologii . Moscow: Znak. ISBN 5-9551-0235-3.

VOLF, E.M. 2009. Funktsionalnaya semantika otsenki. Moscow: LIBROKOM. ISBN 978-5397-00803-7.

MOKIENKO, V. M. - NIKITINA, T. G. - NIKOLAEVA, E. K. 2010. Bolshoj slovar russkikh poslovits. Moscow: OLMA Media Group. ISBN 978-5-373-03250-6.

KARASIK, V.I. 2002. Jazykovoj krug: lichnost, kontsepty, diskurs. Volgograd:” Peremena”. ISBN 5-88234-552-2.

KOVSHOVA M.L. 2013. Lingvo-kulturologicheskij metod vo frazeologii. Moscow: LIBROKOM. ISBN 978-5-397-03945-1.

KRASNYKH, V.V. 2016. Slovar I grammatika lingvokultury. Moscow: Gnozis. ISBN 978-594244-051-0.

CAP -4. 1793. Slovar Akademii Rossijskoj.v.4. Saint-Petersburg.

FROLOVA, 2007. O. E. Mir, stojashij za tekstom: referentsialnye mehanizmy poslovitsy, anekdota, skazki I avtorskogo povestvovatelnogo hudozhestvennogo teksta. Moscow: LKI. ISBN 978-5-382-00600-0.

ABAKUMOVA, O. - KOROSTENSKI, J. 2013. Hodnoceni pravdy a lzi v paremiich/ruskoceske kulturni kody na pozadi anglictiny. In. Auspicia, Recenzovany vedecky casopis pro oblast spolecenskych a humanitnich ved. Ceske Budejovice: Vysoka skola evropskych a regionalnich studii. P.129-134. ISSN 1214-4967.

BITTNEROVA, D. - SHINDLER, F. 2003. Ceska prislovi. Soudoby stav konce 20. stoleti. Praha. Prague. ISBN 80-246-0442-6.

HABERMAS, J. 1987. The Theory of Communicative Action. Boston: Beacon Press, 1987. Vol.1 Reason and the Rationalization of Society. ISBN 0-8070-15-06-7.

VAN VALIN R. Jr. 1993. A Synopsis in Role and Reference Grammar. In. Advances in Role and Reference Grammar. In: Ed. by R. D. Jr. Van Valin. Amsterdam: Benjamins. ISBN 90 27235791.

WIERZBICKA, A. 1980. Lingua Mentalis. Sydney: Academic Press. ISBN 0127500502, 9780127500508 .

\author{
Words: 3604 \\ Characters: 23274 (12,93 standard pages) \\ Prof. Olga Borisovna Abakumova, DrSc. \\ Orel State University \\ Institute of Foreign Languages \\ Ulitsa Komsomol'skaya, 95, Oryol, Orlovskaya oblast' \\ 302026 Orel \\ Russia \\ abakumova-ob@mail.ru \\ Doc. Mgr. Jiří Korostenski, CSc. \\ University of West Bohemia \\ Faculty of Philosophy \\ Department of German and Slavonic languagues and literatures \\ Riegrova 11 \\ 30614 Plzeň \\ Czech Republic \\ jkoroste@kgs.zcu.cz
}

